\title{
ANALISIS PENGARUH LEVERAGE DAN RASIO AKTIVITAS TERHADAP PROFITABILITAS PADA PT INDOFOOD CONSUMER BRANDED PRODUCTS (CBP) SUKSES MAKMUR, TBK
}

\author{
Oleh: \\ Denok Andri Utami \\ S1 Akuntansi \\ Pinondang Nainggolan, Jubi, Elly Susanti
}

Abstrak

Tujuan dari penelitian ini adalah: 1) Untuk mengetahui gambaran leverage, rasio aktivitas dan profitabilitas pada PT Indofood Consumer Branded Products (CBP) Sukses Makmur, Tbk. 2) Untuk mengetahui dan menganalisa pengaruh leverage dan rasio aktivitas terhadap profitabilitas pada PT Indofood Consumer Branded Products (CBP) Sukses Makmur, Tbk baik secara parsial maupun simultan. Teknik analisis data yang digunakan dalam penelitian ini adalah analisis deskriptif kualitatif dan analisis deskriptif kuantitatif yang meliputi uji asumsi klasik, analisis regresi linier berganda, dan uji hipotesis.

Hasil penelitian dapat disimpulkan bahwa: Secara simultan Debt to Equity Ratio (DER) dan Working Capital Turnover (WCT) berpengaruh secara signifikan terhadap Return On Equity (ROE). Secara parsial Debt to Equity Ratio (DER) berpengaruh positif dan signifikan terhadap Return On Equity (ROE) dan Working Capital Turnover (WCT) berpengaruh negatif dan tidak signifikan terhadap Return On Equity (ROE). Hal ini dapat dilihat dari: 1) Hasil regresi linier berganda yaitu: $\mathbf{Y}=\mathbf{0 , 3 2 4}+\mathbf{0 , 1 2 3} \mathbf{X}_{1}-\mathbf{0 , 1 0 1 X _ { 2 }}+\varepsilon$. 2) Koefisien korelasi menyatakan bahwa terdapat hubungan yang sangat kuat antara leverage dan rasio aktivitas terhadap profitabilitas. 3) Koefisien determinasi menyatakan bahwa leverage dan aktivitas berpengaruh sebesar $78,5 \%$ terhadap profitabilitas, sedangkan sisanya sebesar 21,5\% dijelaskan oleh variabel lain yang tidak dibahas dalam penelitian ini.

Kata Kunci: Leverage, Aktivitas, dan Profitablitas

Abstract

The purpose of this research are: 1) To know the overview of leverage, activity ratio and profitability in PT. Indofood Consumer Branded Product (CBP) Sukses Makmur, Tbk. 2) To know and analysis the influence of leverage and activity ratio on profitability in PT Indofood Consumer Branded Products (CBP) Sukses Makmur, Tbk. The data analysis technique used in this research is qualitatif descriptive analysis and quantitatif descriptive analysis. Which includes classic assumption test, multiple linear regression and hyphothesis.

That the simultan Debt to Equity Ratio (DER) and Working Capital Turnover (WCT) effect on Return On Equity (ROE). That the partial Debt to Equity Ratio (DER) positive and significant effect on Return On Equity (ROE) and Working Capital Turnover (WCT) negative and not significant effect on Return n Equity (ROE). It can be seen from: 1) The result of nultiple linear regression analysis $\mathbf{Y = 0 , 3 2 4}+\mathbf{0 , 1 2 3 X _ { 1 }}-\mathbf{0 , 1 0 1 X _ { 2 }}+\varepsilon$. 2) The correlation coefficient states that thereis very strong corre;ation between leverage and activity ratio on profitability. 3) The coefficient of determination states theat leverage and activity ratio have effect of 78,5\% on profitability while remaining $21,5 \%$ is explained by other variables that are nor discussed on this research.

Keywords: Leverage, Activity Ratio, and Profitability

\section{A. PENDAhuluan}

\section{Latar Belakang Masalah}

Persaingan dalam industri manufaktur membuat setiap perusahaan semakin meningkatkan kinerjanya agar tujuan perusahaan tercapai. Pengelolaan kinerja keuangan yang baik juga dapat menarik para investor untuk mempercayakan investasinya pada perusahaan tersebut agar memperoleh keuntungan (profit) yang diharapkan. Kinerja keuangan perusahaan merupakan salah satu alat yang dapat digunakan oleh manajemen perusahaan dalam pengambilan keputusan baik secara internal ataupun eksternal. Hal ini dilakukan untuk daya tarik bisnis yang merupakan salah satu indikator penting dalam persaingan usaha, sedangkan indikator daya tarik bisnis dapat diukur dari profitabilitas.
Suatu perusahaan juga memerlukan dana dari pihak eksternal untuk memenuhi kebutuhan kegiatan operasional perusahaan tersebut. Selain memperhitungkan kewajibannya, suatu perusahaan perlu mengelola aset dalam menjalankan kegiatan perusahaan untuk dapat meningkatkan efektifitas aset yang dimilikinya.

Berikut ini adalah gambaran umum Leverage, Rasio Aktivitas, dan Profitabilitas PT Indofood Consumer Branded Products (CBP) Sukses Makmur, Tbk pada periode tahun 2007 sampai dengan 2014 yang dapat dilihat pada Tabel 1 . 
Tabel I

\begin{tabular}{|c|c|c|c|c|c|c|c|c|}
\hline \multicolumn{9}{|c|}{ 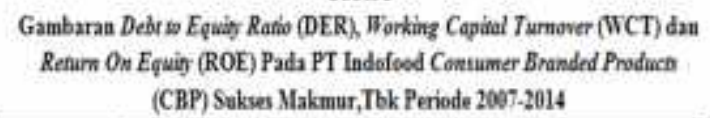 } \\
\hline \multirow{2}{*}{ Variabel } & \multicolumn{8}{|c|}{ Periade } \\
\hline & 2007 & 2009 & 2009 & 2010 & 2011 & 2012 & 2013 & 2014 \\
\hline DER (\%) & 95,09 & 342,18 & 672,23 & 42,72 & 42,14 & 48,69 & 60,32 & 70,11 \\
\hline WCT (Kali) & 3,30 & 4,30 & 256 & 2,26 & 2,19 & 2,22 & 2,21 & 3,30 \\
\hline $\mathrm{ROE}(\%)$ & 2,71 & 15,11 & 34.29 & 19,062 & 19,27 & 19,09 & 17,24 & 1792 \\
\hline
\end{tabular}

\section{Rumusan Masalah}

a. Bagaimana gambaran leverage, rasio aktivitas dan profitabilitas pada PT Indofood Consumer Branded Products (CBP) Sukses Makmur, Tbk?

b. Bagaimana pengaruh leverage dan rasio aktivitas terhadap profitabilitas pada PT Indofood Consumer Branded Products (CBP) Sukses Makmur, Tbk baik secara parsial maupun simultan?

\section{Tujuan Penelitian}

a. Untuk mengetahui gambaran leverage, rasio aktivitas dan profitabilitas pada PT Indofood Consumer Branded Products (CBP) Sukses Makmur, Tbk.

b. Untuk mengetahui dan menganalisa pengaruh leverage dan rasio aktivitas terhadap profitabilitas pada PT Indofood Consumer Branded Products (CBP) Sukses Makmur, Tbk baik secara parsial maupun simultan.

\section{Metode Penelitian}

Desain penelitian yang digunakan adalah Penelitian Kepustakaan (Library Research). Teknik pengumpulan data yang dilakukan menggunakan metode dokumentasi. Hasil data yang diperoleh diuji dengan uji asumsi klasik dan dianalisis secara deskriptif baik bersifat kualitatif dan kuantitatif.

\section{B. LANDASAN TEORI}

\section{Laporan Keuangan}

Laporan keuangan melaporkan apa yang sebenarnya terjadi pada aset, laba, dan dividen selama beberapa tahun terakhir. Inti dari laporan keuangan adalah menggambarkan pos-pos keuangan perusahaan yang diperoleh dalam suatu periode (Brigham dan Joel, 2010:86). Menurut Rudianto (2012:17), laporan keuangan terdiri dari komponenkomponen berikut ini : laporan laba rugi komprehensif, laporan perubahan ekuitas, laporan posisi keuangan, laporan arus kas dan catatan atas laporan keuangan.

Tujuan laporan keuangan adalah menyediakan informasi tentang posisi keuangan, dan laporan arus kas suatu entitas yang bermanfaat bagi sejumlah besar pengguna dalam pengambilan keputusan ekonomi atau siapapun yang tidak dalam posisi dapat meminta laporan keuangan khusus untuk memenuhi kebutuhan informasi tertentu. Menurut Stice et. al (2009:10) para pengguna laporan keuangan diklasifikasikan menjadi dua, yaitu: pemakai internal dan pihak eksternal (Kreditor, Investor, Pemerintah, Karyawan dan
Masyarakat). Laporan keuangan akan lebih bermanfaat jika dilakukan analisis terhadap laporan keuangan tersebut. Menurut Subramanyam dan Wild (2013:34), terdapat lima alat penting untuk analisis keuangan, yaitu terdiri dari: analisis laporan keuangan komparatif, analisis laporan keuangan common-size, analisis rasio, analisis arus kas dan model valuasi.

\section{Rasio Keuangan}

Menurut Horne dan John (2012:163), rasio keuangan adalah indeks yang menghubungkan dua angka akuntansi dan di dapat dengan membagi suatu angka dengan angka yang lainnya. Rasio keuangan digunakan agar dapat mengevaluasi kondisi keuangan perusahaan dan kinerjanya, analisis keuangan keuangan perlu melakukan pemeriksaan atas berbagai aspek kesehatan keuangan perusahaan.

Menurut Kasmir (2010:110) rasio keuangan dibagi atas: rasio likuiditas, rasio hutang, rasio aktivitas, rasio profitabilitas, rasio pertumbuhan dan rasio penilaian.

\section{Leverage}

Hutang merupakan sumber pendanaan eksternal perusahaan yang tercermin dalam struktur modalnya. Hutang merupakan salah satu sumber pembiayaan eksternal yang digunakan oleh perusahaan untuk membiayai kebutuhan dananya. Menurut Stice et al, (2009:145), kebijakan hutang sering diukur dengan debt ratio (rasio utang) yang dihitung sebagai total kewajiban dibagi dengan total aset.

Menurut Kasmir (2010:112), adapun jenisjenis rasio leverage diantaranya terdiri dari: Debt to Assets Ratio (DAR), Debt to Equity Ratio (DER), Long Term Debt to Equity Ratio, Time Interest Earned (TIE) dan Fixed Charge Coverage.

\section{Rasio Aktivitas}

Menurut Horne dan John (2012:172), rasio aktivitas juga disebut sebagai rasio efisiensi atau perputaran, mengukur seberapa efektif perusahaan menggunakan berbagai asetnya. Selanjutnya menurut Kasmir (2010:114), rasio aktivitas terdiri dari: Perputaran Piutang (Receivable Turnover), Hari Rata-rata Penagihan Piutang (Days of Receivabele), Perputaran Persediaan (Inventory Turnover), Perputaran Modal Kerja (Working Capital Turnover), Perputaran Aset Tetap (Fixed Assets Turnover) dan Perputaran Aset (Assets Turnover).

\section{Profitabilitas}

Tujuan akhir yang ingin dicapai suatu perusahaan yang terpenting adalah memperoleh laba atau keuntungan yang maksimal. Rasio profitabilitas adalah rasio untuk mengukur tingkat efektifitas pengelolaan (manajemen) perusahaan yang ditunjukkan oleh jumlah keuntungan yang dihasilkan dari penjualan dan investasi. Adapun jenis-jenis rasio profitabilitas menurut Kasmir (2010:111), adalah sebagai berikut: Profit Margin (Profit Margin 
on Sales), Return On Assets (ROA), Return on Investment (ROI), Return on Equity (ROE) dan Laba Per Lembar Saham (Earning Per Share).

\section{Pengaruh Leverage Terhadap Profitabilitas \\ Menurut Kasmir (2010:158), leverage akan} menunjukkan besarnya modal sendiri yang dijadikan untuk jaminan hutang. Sedangkan profitabilitas merupakan tingkat keuntungan bersih yang mampu diraih oleh perusahaan pada saat menjalankan operasional perusahaannya. Profitabilitas menggambarkan pendapatan yang dimiliki perusahaan untuk membiayai investasi. Investasi menunjukkan kemampuan dari modal yang diinvestasikan dalam keseluruhan aset untuk menghasilkan keuntungan bagi investor. Sedangkan menurut Atmaja (2003:262), perusahaan cenderung memelihara kemungkinan berhutang untuk dapat mengambil keuntungan dari kesempatan investasi yang baik tanpa harus menerbitkan saham baru pada harga yang turun akibat bad signaling.

Perusahaan dengan tingkat pengembalian yang tinggi atas investasi, menggunakan hutang yang relatif kecil karena tingkat pengembalian yang tinggi memungkinkan perusahaan untuk membiayai sebagian pendanaan internal. Dengan laba yang besar akan mempengaruhi manajemen perusahaan dalam menggunakan hutang. Pihak manajemen perusahaan juga dapat menyimpulkan untuk menggunakan laba bersih sebagai pilihan alternatif utama untuk membiayai kegiatan operasional perusahaan dengan meminimalisasi pengggunaan hutang.

\section{Pengaruh Rasio Aktivitas Terhadap} Profitabilitas

Menurut Brigham dan Joel (2012:136), jika investor mengakuisisi aset yang begitu tinggi dan perusahaan memiliki terlalu banyak aset, maka biaya modalnya terlalu tinggi dan laba (profit) akan tertekan. Hal tersebut akan menunjukkan bahwa aset yang terlalu tinggi juga tidak menjamin suatu perusahaan akan memperoleh profitabilitas yang tinggi. Modal kerja yang tinggi akan mempengaruhi biaya bunga modal yang telah tertanam oleh investor yang mengakuisisi saham atau aset pada perusahaan tersebut.

\section{PEMBAHASAN}

\section{Analisis}

a. Analisis Deskriptif Kualitatif

Gambaran Debt to Equity Ratio (DER) PT Indofood CBP Sukses Makmur, Tbk yang terdaftar di Bursa Efek Indonesia dapat dilihat pada tabel berikut ini :
Tabel 2 Tbk yang Terdaftar di Bars Efek Indenesia Periode 2007-2014

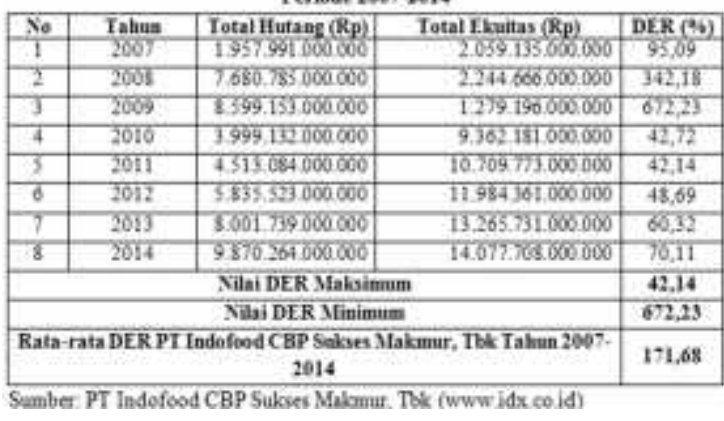

Berdasarkan tabel 2 di atas nilai DER maksimum PT Indofood CBP Sukses Makmur, Tbk mencapai angka $672,23 \%$ yang berarti bahwa jumlah hutang lebih besar dari modal perusahaan tersebut. Hal tersebut menunjukkan bahwa setiap Rp. 100,hutang dapat mengembalikan ekuitas bersih sebesar Rp 67.223. Nilai DER yang tinggi tersebut terjadi ketika restrukturisasi PT Indofood Sukses Makmur, Tbk menjadi PT Indofood Consumer Branded Products (CBP) Sukses Makmur, Tbk. Karena pada tahun 2008 sampai dengan 2009 semua aset, kewajiban, dan kegiatan usaha perusahaan yang menggabungkan diri dialihkan ke ICBP. Hal tersebut yang menyebabkan tingkat Debt to Equity Ratio (DER) melonjak tinggi. Sedangkan pada tahuntahun yang lainnya nilai Debt To Equity Ratio (DER) cenderung berfluktuasi. Sedangkan untuk nilai Debt To Equity Ratio (DER) minimum yaitu mencapai angka $42,14 \%$ yang berarti bahwa setiap Rp. 100,- hutang dapat mengembalikan Rp. 4.214,ekuitas perusahaan tersebut. Hal ini terjadi setahun setelah restrukturisasi PT Indofood CBP Sukses Makmur, Tbk. Pada saat itu jumlah hutang lebih kecil dibandingkan dengan ekuitas bersih yang dimilikinya. Hal tersebut menunjukkan bahwa para investor cenderung menanamkan modal pada perusahaan baru dan dianggap dapat memberikan nilai keuntungan (profit) yang tinggi.

Dari hasil penelitian dapat disimpulkan bahwa rata-rata nilai Debt To Equity Ratio (DER) PT Indofood CBP Sukses Makmur, Tbk pada Periode 2007-2014 berada pada nilai di atas $100 \%$, yang berarti bahwa jumlah hutang lebih besar dari jumlah modalnya. Debt To Equity Ratio (DER) dianggap wajar jika di bawah angka $100 \%$. Semakin besar angka Debt To Equity Ratio (DER) suatu perusahaan maka manajemen perusahaan harus semakin kerja keras untuk menjaga arus kas perusahaan yang sedang dijalankan. Risiko yang tinggi juga diharapkan dapat memberikan keuntungan yang lebih pula.

Gambaran Working Capital Turnover (WCT) PT Indofood CBP Sukses Makmur, Tbk yang terdaftar di Bursa Efek Indonesia dapat dilihat pada tabel di bawah ini :

\begin{tabular}{lllll}
\hline \hline Jurnal SULTANIST & ISSN : 2338-4328 & Vol. 4, No. 1, & JUNI 2016 & 46
\end{tabular}


Tabel 3

Rata-Rata Working Capina/ Tumover (WCT) PT ludofood CBP Sukses Makmur, Tbk yang Terdaftar di Bursa Efek Indenesia Periode 2007.2014

\begin{tabular}{|c|c|c|c|c|}
\hline \\
\hline so. & Tahum & $\begin{array}{l}\text { Total Penjualan Bersih } \\
(\mathbb{R p})\end{array}$ & $\begin{array}{l}\text { Total Aset Lancar } \\
\left(\mathrm{Rp}^{2}\right)\end{array}$ & $\begin{array}{l}\text { WCT } \\
\text { (Kali) }\end{array}$ \\
\hline 1 & 2007 & 9.494 .735000000 & 2318.487000 .000 & \\
\hline 2 & 2008 & 12.042 .852000000 & $3,647,087,000,000$ & 3,30 \\
\hline 3 & 2009 & 16332007000.000 & 3.800 .017000 .000 & 4,30 \\
\hline 4 & 2010 & 17,960120000000 & $7,017,850000000$ & 2,56 \\
\hline 3 & 2011 & 19307.155000000 & 8580.311000 .000 & 2,26 \\
\hline 6 & 2012 & $21,716,911000000$ & 9922.062000000 & 2,19 \\
\hline 7 & 2013 & 25.094 .651000 .000 & 11.521 .715 .000 .000 & 2,22 \\
\hline 8 & 2014 & 30.022 .265000000 & 13.003 .527000000 & 2,21 \\
\hline \multicolumn{4}{|c|}{ 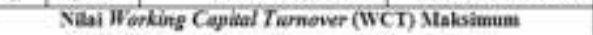 } & 4,30 \\
\hline \multicolumn{4}{|c|}{ Nilai Warking Capinal Turnower (WC1) Mtinimum } & 2,19 \\
\hline \multicolumn{4}{|c|}{$\begin{array}{l}\text { Rata-rata WCT PT ladofood CBP Salses Mtakinur, Tok Tahan } \\
\qquad 2007-2014\end{array}$} & 2,89 \\
\hline
\end{tabular}

Berdasarkan tabel 3 di atas, nilai Working Capital Turnover (WCT) minimum PT Indofood CBP Sukses Makmur, Tbk mencapai angka 2,19 kali per tahun. Artinya bahwa setiap Rp. 100,00,- modal kerja dapat menghasilkan penjualan sebesar Rp. 219,00,-. Nilai minimum tersebut menunjukkan bahwa pengelolaan modal kerja yang dimiliki perusahaan tersebut kurang maksimal. Keadaan ini menunjukkan belum optimalnya para manajer mengelola kebijakan modal kerja untuk meningkatkan profitabilitas perusahaan. mengelola kebijakan modal kerja untuk meningkatkan profitabilitas perusahaan. Sedangkan nilai Working Capital Turnover (WCT) maksimum PT Indofood CBP Sukses Makmur, Tbk mencapai hingga 4,30 kali yang berarti bahwa dana yang tertanam dalam modal kerja berputar rata-rata 4,30 kali dalam setahunnya. Atau yang berarti bahwa setiap Rp. 100,00,- modal kerja dapat menghasilkan Rp. $430,00,-$. Modal kerja yang tertanam oleh investor sangat besar sehingga mengakibatkan perputaran modal kerja yang lebih besar juga. Dengan perputaran modal kerja yang besar, akan memperkecil risiko kerugian akibat penurunan harga penjualan serta mampu menghemat biaya penyimpanan dan memelihara persediaan untuk meningkatkan penjualan.

Dari penelitian tersebut dapat disimpulkan bahwa nilai Working Capital Turnover (WCT) PT Indofood CBP Sukses Makmur, Tbk pada Periode 2007 sampai dengan 2014 berada pada nilai di atas 1. Karena perusahaan setidaknya dapat mengembalikan modal kerja yang diinvestasikan sekali dalam setahunnya agar dapat memperoleh laba (profit) yang diharapkan. Nilai Working Capital Turnover (WCT) PT Indofood CBP Sukses Makmur, Tbk pada Periode 2007-2014 masih dapat dikatakan wajar. Hanya saja ada beberapa tahun yang menunjukkan angka Working Capital Turnover (WCT) yang berada dibawah rata-rata, tapi masih dapat dikatakan wajar karena tidak menjadikan perusahaan tidak dapat mengembalikan modal kerja yang tertanam dari para investor. Karena menurut Riyanto (2009:65), perputaran modal kerja dibutuhkan bagi perusahaan untuk menjalankan aktivitas usaha setiap harinya dan untuk menjamin berlangsungnya suatu perusahaan. Dengan semakin besarnya tingkat perputaran modal kerja akan menambah efisiensi suatu perusahaan dalam mengelola aset yang dimilikinya.

Gambaran Return On Equity (ROE) pada PT Indofood CBP Sukses Makmur, Tbk yang terdaftar di Bursa Efek Indonesia dapat dilihat pada tabel di bawah ini :

Tabel 4

Rata-Rata Return On Equig (ROE) PT Indofood CBP Sukses Makmar, Thk yang Terdaftar di Bursa E. fek IndoseniaPeriode 2007-2014

\begin{tabular}{|c|c|c|c|c|}
\hline $\mathbf{S o}_{\mathbf{6}}$ & Tahmin & Laba Bersili (Rp) & Total Ekwitss (kp) & ROE \\
\hline $\mathrm{t}$ & 2007 & $55.866,000000$ & 2.059135000000 & 2,71 \\
\hline 2 & 2008 & 399,0090000000 & 2.244666000000 & 15,11 \\
\hline 3 & 2009 & $1.67 .21900 \times 00$ & 1.279 .13600000 & 84,29 \\
\hline 4 & 2010 & 1.8368522000000 & 9.362 .181000000 & 19,02 \\
\hline 5 & 2011 & 2064,090000000 & 10.709 .77 .000 .000 & {$[9,27$} \\
\hline 6 & 2012 & $2.287,242000,000$ & 11984361.000 .000 & 19,09 \\
\hline 7 & 2013 & 2.286 .699000000 & 13.265 .731 .000 .000 & 17,24 \\
\hline 8 & 2014 & 2.522 .3280000000 & $1+.077 .008 .000 .000$ & 17,92 \\
\hline \multicolumn{4}{|c|}{ Nilai Renurn Om Equiny (ROE) Mlaksimmm } & 84.29 \\
\hline \multicolumn{4}{|c|}{ Xilai Retwrn On Equing (ROE) Minimum } & 3,71 \\
\hline \multicolumn{4}{|c|}{$\begin{array}{l}\text { Rata rata Return On Equalty (ROE) PT Indofood CBP Sukses } \\
\text { Malanur, Tbk Tahum 2007-2014 }\end{array}$} & 24,40 \\
\hline
\end{tabular}

Berdasarkan tabel 4 di atas, nilai Return On Equity (ROE) maksimum PT Indofood CBP Sukses Makmur, Tbk mencapai angka 84,29\%. Hal tersebut menunjukkan bahwa setiap Rp. 100,- laba bersih dapat mengembalikan ekuitas bersih sebesar Rp. 8.429,-. Angka ini ditunjukkan pada saat restrukturisasi PT Indofood Sukses Makmur, Tbk menjadi PT Indofood CBP Sukses Makmur, Tbk. Ini berarti pada tahun 2009, total pengembalian ekuitas PT Indofood CBP Sukses Makmur sebesar 84,29\%. Pengembalian ekuitas untuk menghasilkan keuntungan dianggap tinggi dan menjadikan dampak yang baik bagi perusahaan. Tetapi ketika ekuitas dan laba bersih dinaikkan pertahun, nilai Return On Equity (ROE) cenderung menurun tiap tahunnya.

Selanjutnya nilai Return On Equity (ROE) minimum yang menunjukkan pada angka $2,71 \%$. Yang berarti bahwa setiap Rp. 100,- laba bersih dapat mengembalikan Rp. 271,- ekuitas yang dimiliki perusahaan tersebut. Hal ini terjadi pada tahun 2007 yang berarti bahwa tingkat keuntungan yang diberikan dari total ekuitas hanya sebesar $2,71 \%$. Hal ini terjadi ketika perusahaan baru didirikan menjadi perusahaan go public. Sehingga mengakibatkan kemampuan perusahaan dalam menghasilkan laba atas ekuitasnya relatif rendah. Tetapi pada tahun selanjutnya Return On Equity (ROE) berfluktuasi berdasarkan modal dan jumlah laba bersih. Tingginya nilai Return On Equity (ROE) menunjukkan penilaian atau harapan yang baik para investor terhadap perusahaan. Semakin tinggi rasio ini, akan memberikan prospek yang baik bagi pihak manajemen perusahaan dan para investor atau bagi pihak di luar perusahaan, terutama pihak-pihak yang memiliki hubungan atau kepentingan dengan perusahaan.

\section{b. Analisis Deskriptif Kuantitatif}

1) Analisis Regresi Linier Berganda

Pengujian regresi linier sederhana pada penelitian ini menggunakan SPSS (Statistical Package for Social Science) versi 17 dengan hasil distribusi data normal dapat dilihat pada Tabel 5.

\begin{tabular}{lllll}
\hline \hline Jurnal SULTANIST & ISSN : 2338-4328 & Vol. 4, No. 1, & JUNI 2016 & 47
\end{tabular}


Tabel 5

Regresi Linier Berganda

\begin{tabular}{|c|c|c|c|}
\hline \multirow[b]{2}{*}{ Model } & \multicolumn{2}{|c|}{ Unstardarizes Coetticients } & \multirow{2}{*}{$\begin{array}{c}\text { Standadoce Coeffidents } \\
\text { Beta }\end{array}$} \\
\hline & B & StIEngr & \\
\hline 1 (Constat) & 324 & 215 & \\
\hline DER & , 123 & 036 & 1,119 \\
\hline MCT & 101 & 0066 & .760 \\
\hline
\end{tabular}

\section{Sumber. Hasil Pengathan Deta (SPSS Statitacic 17.0)}

Berdasarkan Tabel 5, maka model persamaan regresi bergandaadalah sebagai berikut:

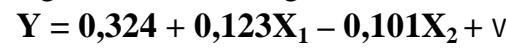

Dari persamaan regresi di atas, dapat diartikan bahwa Debt to Equity Ratio (DER) memiliki pengaruh positif terhadap Return On Equity (ROE). Hal ini berarti jika Debt to Equity Ratio (DER) bertambah maka Return On Equity (ROE) akan bertambah

Sedangkan Working Capital Turnover (WCT) memiliki pengaruh negatif terhadap Return On Equity (ROE). Hal ini berarti jika Working Capital Turnover (WCT) bertambah maka Return On Equity (ROE) akan berkurang.

2) Koefisien Korelasi dan Koefisien Determinasi

Hasil pengolahan data SPSS untuk koefisien korelasi disajikan pada Tabel 6 .

Tabel 6

Koefisien Korelasi dan Determinas

Nodet Smmeng

\begin{tabular}{|c|c|c|c|c|}
\hline Misdet & $\mathrm{R}$ & RSquare & Aquated R Squaes & 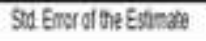 \\
\hline 1 & $8 E^{\prime}$ & 705 & 699 & 13611 \\
\hline
\end{tabular}

D. Dependert vivisble $\mathrm{ROE}$

\section{Sumber Hasil Pengolahan Data (SPSS Statistic 17.0)}

Dari Tabel 6 diperoleh hasil $\mathrm{R}$ adalah sebesar 0,886. Dengan demikian dapat dikatakan bahwa hubungan Debt to Equity Ratio (DER) dan Working Capital Turnover (WCT) dengan variabel dependen Return On Equity (ROE) sangat kuat pada PT Indofood CBP Sukses Makmur, Tbk Periode 20072014. Sedangkan nilai r square adalah sebesar 0,785 atau 78,5\% yang berarti bahwa secara bersama-sama Debt to Equity Ratio (DER) dan Working Capital Turnover (WCT) berpengaruh secara 78,5\% terhadap Return On Equity (ROE), sedangkan sisanya sebesar 21,5\% Return On Equity (ROE) dapat dipengaruhi variabel lain yang tidak dapat dimasukkan dalam penelitian ini.

\section{3) Uji Hipotesis}

\section{a) Uji Simultan (Uji F)}

Uji F dilakukan untuk mengetahui apakah variabel independen secara bersama-sama (simultan) mempunyai pengaruh terhadap variabel dependen. Derajat kepercayaan yang digunakan adalah 0,05. Apabila nilai $\mathrm{F}$ hasil perhitungan lebih besar daripada nilai $\mathrm{F}$ menurut tabel maka hipotesis alternatif yang menyatakan bahwa semua variabel independen secara simultan berpengaruh signifikan terhadap variabel dependen. Pembuktian dilakukan dengan cara membandingkan nilai kritis, F(tabel) dengan $\mathrm{F}$ (hitung) yang terdapat pada tabel analisis $d f$ variance.

Hasil perkiraan dari nilai $F_{\text {hitung }}$ dalam penelitian ini disajikan pada Tabel 7.

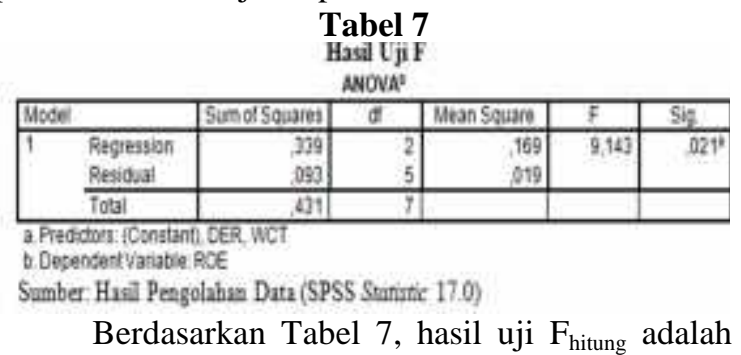
9,143 dan dengan menggunakan tabel $\mathrm{F}$ diperoleh nilai $F_{\text {tabel }}$ sebesar 5,786. Hal ini menunjukkan bahwa $F_{\text {hitung }}(9,143)>F_{\text {tabel }}(5,786)$ dengantingkat signifikansi $0,021<0,05$ sehingga $\mathrm{H}_{0}$ ditolak, yang berarti bahwa Debt to Equity Ratio (DER) dan Working Capital Turnover (WCT) berpengaruh signifikan terhadap Return On Equity (ROE) pada PT Indofood CBP Sukses Makmur, Tbk pada periode 2007 sampai dengan 2014.

\section{b) Uji Parsial (Uji t)}

Uji t merupakan suatu cara untuk mengukur apakah suatu variabel independen bukan merupakan penjelas yang signifikan terhadap variabel dependen. Dalam pengujian ini digunakan uji $t$ dua ujung, karena hipotesis yang ditunjukkan belum menunjukkan arah, yaitu terdapat pengaruh (tidak menunjukkan pengaruh positif atau negatif). Hasil perkiraan nilai $t_{\text {hitung }}$ dalam penelitian ini dapat dilihat pada Tabel 8 .

\section{Tabel 8}

Hasil Uji t (Uji Parsial)

\begin{tabular}{|c|c|c|c|c|c|c|c|}
\hline \multirow[b]{3}{*}{ Nodel } & & \multirow{3}{*}{\begin{tabular}{|c|}
$\begin{array}{l}\text { Shandardcod } \\
\text { Coefificents }\end{array}$ \\
Eea \\
\end{tabular}} & \multicolumn{5}{|c|}{ Coeffikients ${ }^{*}$} \\
\hline & & & \multirow[b]{2}{*}{1} & \multirow[b]{2}{*}{ sid } & \multicolumn{3}{|c|}{ Contesbon } \\
\hline & & & & & Zarositem & Faลa1 & $P_{21}$ \\
\hline \multirow[t]{3}{*}{5} & (Constamt) & & 1504 & .199 & & & \\
\hline & DEA & 1,119 & 3,431 & Q15 & 853 & 851 & 752 \\
\hline & WCT & -360 & $-4,167$ & 296 & 460 & .463 & -242 \\
\hline
\end{tabular}

r. Hasil Pengolahm Data (SPSS Statirtic 170)

Berdasarkan Tabel 8, menunjukkan hasil pengujian statistik uji-t yang menjelaskan pengaruh variabel independen terhadap variabel dependen secara parsial sebagai berikut:

(1) $t_{\text {hitung }}>t_{\text {tabel }}(3,631>2,571)$ atau Sig. < alpha $(0,015<0,05)$ maka $\mathrm{H}_{0}$ ditolak, yang berarti bahwa Debt to Equity Ratio (DER) berpengaruh positif dan signifikan secara parsial terhadap Return On Equity (ROE) pada PT Indofood CBP Sukses Makmur, Tbk pada periode 2007 sampai dengan 2014.

(2) $t_{\text {hitung }}<t_{\text {tabel }}(1,167<2,571)$ atau Sig. $>$ alpha $(0,296>0.05)$ maka Ha diterima, yang berarti bahwa Working Capital Turnover (WCT) berpengaruh negatif dan tidak signifikan secara parsial terhadap Return On Equity (ROE) pada PT Indofood CBP Sukses Makmur, Tbk pada periode 2007 sampai dengan 2014. 
2. Evaluasi

a. Evaluasi Leverage PT Indofood CBP Sukses Makmur, Tbk yang Terdaftar di Bursa Efek Indonesia

Margaretha (2011:26), mengungkapkan bahwa rasio leverage merupakan kemampuan perusahaan untuk melunasi hutang. Semakin besar rasio ini menunjukkan semakin besar tingkat ketergantungan perusahaan terhadap pihak eksternal (kreditor) dan semakin besar biaya utang yang harus dibayar perusahaan. Hal ini akan berdampak pada profitabilitas karena sebagian pendapatan digunakan untuk membayar utang. Dalam penelitian ini, penulis menggunakan rasio Debt to Equity Ratio (DER).

Dari hasil penelitian, diperoleh rata-rata nilai Debt to Equity Ratio (DER) pada PT Indofood CBP Sukses Makmur, Tbk Periode 2007 sampai dengan 2014 adalah sebesar $171,68 \%$ yang berarti bahwa total hutang perusahaan lebih tinggi dari jumlah ekuitasnya. Untuk nilai Debt To Equity Ratio (DER) dibawah rata-rata yaitu pada tahun 2007, 2010, 2011, 2012, 2013, dan tahun 2014. Menurut Atmaja (2003:262), perusahaan cenderung memelihara kemungkinan berhutang untuk dapat mengambil keuntungan dari kesempatan investasi yang baik tanpa harus menerbitkan saham baru pada harga yang turun akibat bad signaling. Sedangkan Nilai Debt To Equity Ratio (DER) diatas rata-rata terdapat pada tahun 2008 dan 2009, ini menunjukkan bahwa perusahaan sangat agresif dengan mencari pinjaman baik jangka pendek maupun jangka panjang. Menurut Atmaja (2003:263), perusahaan dengan tingkat pengembalian yang tinggi atas investasi, menggunakan hutang yang relatif kecil karena tingkat pengembalian yang tinggi memungkinkan perusahaan untuk membiayai sebagian pendanaan internal. Dengan laba yang besar akan mempengaruhi keputusan manajemen perusahaan dalam menggunakan hutang. Risiko yang tinggi juga diharapkan dapat memberikan keuntungan yang lebih pula.

b. Evaluasi Rasio Aktivitas PT Indofood CBP Sukses Makmur, Tbk yang Terdaftar di Bursa Efek Indonesia

Dari hasil penelitian, dapat diketahui rata-rata Working Capital Turnover (WCT) pada PT Indofood CBP Sukses Makmur, Tbk pada Periode 2007 sampai dengan 2014 adalah sebesar 2,89 kali. Dapat disimpulkan bahwa nilai Working Capital Turnover (WCT) PT Indofood CBP Sukses Makmur, Tbk pada Periode 2007 sampai dengan 2014 adalah diatas 1 . Karena perusahaan setidaknya dapat mengembalikan modal kerja yang diinvestasikan sekali dalam setahunnya agar dapat memperoleh laba (profit) yang diharapkan. Nilai Working Capital Turnover (WCT) PT Indofood CBP Sukses Makmur, Tbk pada Periode 2007-2014 masih dapat dikatakan wajar. Karena menurut Riyanto (2009:65), perputaran modal kerja dibutuhkan bagi perusahaan untuk menjalankan aktivitas usaha setiap harinya dan untuk menjamin berlangsungnya suatu perusahaan. Besarnya perputaran modal kerja bergantung pada lamanya periode pengembalian modal kerja tersebut. Dengan jumlah pengeluaran setiap harinya yang tetap, tetapi dengan makin lamanya periode perputarannya, maka jumlah modal kerja yang dibutuhkan makin besar. Demikian pula halnya dengan periode perputaran yang tetap, dengan makin besarnya jumlah pengeluran kas setiap harinya, kebutuhan modal kerja pun makin besar.

c. Evaluasi Profitabilitas PT Indofood CBP Sukses Makmur, Tbk yang Terdaftar di Bursa Efek Indonesia.

Dari hasil penelitian, nilai rata-rata Return On Equity (ROE) PT Indofood CBP Sukses Makmur, Tbk sebesar 0,24 yang berarti bahwa tingkat pengembalian ekuitas terhadap laba bersih sebesar 24\%. Tingginya nilai Return On Equity (ROE) menunjukkan penilaian atau harapan yang baik para investor terhadap perusahaan.

Nilai Return On Equity (ROE) yang terendah terjadi pada tahun 2007, karena modal yang kecil tidak menjamin perusahaan untuk menghasilkan laba yang tinggi. Jika perusahaan ingin mendapatkan laba yang tinggi juga harus menaikkan modal dengan mempertinggi risiko yang akan dihadapi. Menurut Brigham dan Joel (2012:136), jika investor mengakuisisi aset yang begitu tinggi dan perusahaan memiliki terlalu banyak aset, maka biaya modalnya terlalu tinggi dan laba (profit) akan tertekan. Di tahun berikutnya, tingkat Return On Equity (ROE) cenderung berfluktuatif. Perusahaan mengambil kebijakan untuk menaikkan modal dan berharap agar mendapatkan tingkat pengembalian yang tinggi pula.

d. Evaluasi Pengaruh Leverage Terhadap Profitabilitas Pada PT Indofood CBP Sukses Makmur, Tbk yang Terdaftar di Bursa Efek Indonesia.

Dari hasil pengujian hipotesis diperoleh $\mathrm{t}_{\text {hitung }}$ $>t_{\text {tabel }}(3,631>2,447)$ atau Sig. < alpha $(0,015<$ $0,05)$ yang berarti bahwa $\mathrm{H}_{0}$ ditolak, hal tersebut menunjukkan bahwa Debt to Equity Ratio (DER) berpengaruh positif atau signifikan terhadap Return On Equity (ROE) pada PT Indofood CBP Sukses Makmur, Tbk pada Periode 2007 sampai dengan 2014. Dari hasil uji t memberikan gambaran jika nilai Debt to Equity Ratio (DER) memberikan kontribusi yang baik dalam meningkatkan Return On Equity (ROE) pada perusahaan tersebut.

Hal ini sejalan dengan teori Riyanto (2009:375) yang mengatakan bahwa penggunaan hutang dapat meningkatkan pendapatan bagi suatu perusahaan untuk membiayai biaya operasionalnya. Karena perusahaan tersebut mengandalkan modal dari luar (kreditur). Dengan uji ini juga dapat memberikan gambaran bahwa perusahaan dapat menjaga arus kas (cash flow) perusahaan untuk bisa menutup pengeluaran dan bisa menghasilkan keuntungan perusahaan lebih besar. Karena perusahaan tersebut juga meyakini dengan tingkat

\begin{tabular}{lllll}
\hline Jurnal SULTANIST & ISSN : 2338-4328 & Vol. 4, No. 1, & JUNI 2016 & 49
\end{tabular}


resiko yang besar dapat memberikan tingkat keuntungan bagi manajemen perusahaan dan para investor.

\section{e. Evaluasi Pengaruh Aktivitas Terhadap Profitabilitas Pada PT Indofood CBP Sukses Makmur, Tbk yang Terdaftar di Bursa Efek Indonesia. \\ Dari hasil penelitian diperoleh nilai $\mathrm{t}_{\text {hitung }}<$} $\mathrm{t}_{\text {tabel }}(1,167<2,447)$ atau sig. $>$ alpha $(0,296>0.05)$ maka $\mathrm{H}_{0}$ diterima, yang berarti bahwa Working Capital Turnover (WCT) berpengaruh negatif dan tidak signifikan terhadap Return On Equity (ROE) pada PT Indofood CBP Sukses Makmur, Tbk pada Periode 2007 sampai dengan 2014.

Hubungan yang negatif dan tidak signifikan antara WCT dengan ROE disebabkan oleh banyaknya aset menganggur yang mengakibatkan banyaknya persediaan di gudang yang berpotensi untuk menghasilkan keuntungan (profitabilitas) bagi perusahaan tersebut. Pengelolaan aset yang menganggur belum optimal sehingga memperkecil penjualan yang mengakibatkan rendahnya pengembalian modal kerja para investor. Hal ini sejalan dengan pendapat Brigham dan Joel (2012:136) yang mengatakan bahwa, jika investor mengakuisisi aset yang begitu tinggi dan perusahaan memiliki terlalu banyak aset, maka biaya modalnya terlalu tinggi dan laba (profit) akan tertekan.

f. Evaluasi Pengaruh Leverage dan Aktivitas Terhadap Profitabilitas Pada PT Indofood CBP Sukses Makmur, Tbk yang Terdaftar di Bursa Efek Indonesia.

Dari hasil persamaan regresi linier berganda yaitu $\mathrm{ROE}=0,324+0,123 \mathrm{DER}-0,101 \mathrm{WCT}+\varepsilon$, menunjukkan bahwa Debt to Equity Ratio (DER) berpengaruh positif dan signifikan artinya jika DER perusahaan naik maka akan diikuti dengan kenaikan Return On Equity (ROE) yang diperoleh oleh perusahaan tersebut. Selanjutnya Working Capital Turnover (WCT) berpengaruh negatif dan tidak signifikan terhadap Return On Equity (ROE), artinya pengaruh yang negatif menunjukkan ketika nilai Working Capital Turnover (WCT) menurun akan diikuti dengan kenaikan Return On Equity (ROE).

Hasil uji F pada penelitian ini menunjukkan bahwa nilai $F_{\text {hitung }}$ adalah 9,143 dengan tingkat signifikansi 0,021 yang lebih kecil dari 0,05 dan nilai df1=2 dan df2=5 diperoleh nilai $F_{\text {tabel }}$ sebesar 5,79. Karena $\mathrm{F}_{\text {hitung }}>\mathrm{F}_{\text {tabel }}$ maka $\mathrm{H}_{0}$ ditolak, yang berarti bahwa Debt to Equity Ratio (DER) dan Working Capital Turnover (WCT) berpengaruh signifikan terhadap Return On Equity (ROE) pad PT Indofood CBP Sukses Makmur, Tbk pada Periode 2007 sampai dengan 2014

Berdasarkan hasil penelitian, rata-rata PT Indofood CBP Sukses Makmur, Tbk periode 2007. 2014 menggunakan hutang yang tinggi. Terlihat pada nilai Debt to Equity Ratio (DER) yang meningkat setiap tahunnya. Penggunaan hutang yang tinggi akan menyebabkan timbulnya biaya kebangkrutan, biaya keagenan, beban bunga yang semakin besar dan sebagainya. Apabila biaya kebangkrutan semakin besar, tingkat keuntungan yang disyaratkan oleh pemegang saham juga semakin tinggi. Biaya modal hutang juga akan semakin tinggi karena pemberi pinjaman akan membebankan bunga yang tinggi sebagai kompensasi kenaikan risiko kebangkrutan. Oleh karena itu, perusahaan akan terus menggunakan hutang apabila manfaat hutang (penghematan pajak dari hutang) masih lebih besar dibandingkan dengan biaya kebangkrutan. Jika biaya kebangkrutan lebih besar dibandingkan dengan penghematan pajak dari hutang, perusahaan akan menurunkan tingkat hutangnya.

Dari hasil uji koefisien korelasi diperoleh hasil $\mathrm{R}$ adalah sebesar 0,886. Hal tersebut menunjukkan bahwa korelasi atau hubungan antara Debt to Equity Ratio (DER) dan Working Capital Turnover (WCT) terhadap Return On Equity (ROE) pada PT Indofood CBP Sukses Makmur, Tbk Periode 2007-2014 adalah sangat kuat. Hubungan tersebut menunjukkan bahwa perusahaan harus lebih memperhatikan tingkat hutang untuk menghasilkan pengembalian yang diharapkan bagi para manajemen dan para pemegang saham.

Nilai koefisien determinasi (R Square) adalah sebesar 0,785 atau $78,5 \%$ yang berarti bahwa secara bersama-sama Debt to Equity Ratio (DER) dan Working Capital Turnover (WCT) berpengaruh secara 78,5\% terhadap Return On Equity (ROE), sedangkan sisanya sebesar $21,5 \%$ Return On Equity (ROE) dapat dipengaruhi variabel lain yang tidak dapat dijelaskan dalam penelitian ini. Seperti Debt to Assets Ratio (DAR), Long Term Debt to Equity Ratio (LTDER), Total Assets Turnover (TAT), Fixed Assets Turnover (FAT), Inventory Turnover (IT), Return On Assets (ROA), Net Profit Margin (NPM).

\section{KESIMPULAN DAN SARAN}

\section{Kesimpulan}

a. Dari hasil penelitian, nilai rata-rata Return On Equity (ROE) PT Indofood CBP Sukses Makmur, Tbk sebesar 0,24 yang berarti bahwa tingkat pengembalian ekuitas terhadap laba bersih sebesar $24 \%$. Tingginya nilai Return On Equity (ROE) menunjukkan penilaian atau harapan yang baik para investor terhadap perusahaan. Hal ini menunjukkan bahwa ratarata profitabilitas PT Indofood CBP Sukses Makmur, Tbk adalah sebesar 0,24. Angka 0,24 tersebut mengandung arti bahwa $24 \%$ rupiah dari total modal dari pemilik adalah untuk menghasilkan laba (profit).

b. Dari hasil persamaan regresi linier berganda yaitu $\mathrm{Y}=0,324+0,123 \mathrm{X}_{1}-0,101 \mathrm{X}_{2}+\varepsilon$, menunjukkan bahwa Debt to Equity Ratio (DER) berpengaruh positif dan signifikan terhadap Return On Equity (ROE) dan Working Capital Turnover (WCT) berpengaruh negatif dan tidak signifikan terhadap Return On Equity (ROE) pada PT Indofood CBP Sukses Makmur, Tbk Periode 2007 sampai dengan 2014. 
c. Dari hasil pengujian hipotesis untuk $\mathrm{X}_{1}$ [Debt to Equity Ratio (DER)] diperoleh bahwa $\mathrm{H}_{0}$ ditolak, yang berarti bahwa DER berpengaruh dan signifikan secara parsial terhadap Return On Equity (ROE) sedangkan hasil uji hipotesis untuk $\mathrm{X}_{2}$ [Working Capital Turnover (WCT)] bahwa maka $\mathrm{H}_{0}$ diterima, yang berarti bahwa WCT berpengaruh tidak signifikan secara parsial terhadap Return On Equity (ROE) pada PT Indofood CBP Sukses Makmur, Tbk pada Periode 2007 sampai dengan 2014.

d. Hasil uji F menunjukkan bahwa bahwa Debt to Equity Ratio (DER) dan Working Capital Turnover (WCT) berpengaruh secara simultan dan signifikan terhadap Return On Equity (ROE) pad PT Indofood CBP Sukses Makmur, Tbk pada Periode 2007 sampai dengan 2014

e. Dari hasil uji koefisien korelasi diperoleh hasil $\mathrm{R}$ adalah sebesar 0,886 . Hal tersebut menunjukkan bahwa korelasi atau hubungan antara Debt to Equity Ratio (DER) dan Working Capital Turnover (WCT) terhadap Return On Equity (ROE) pada PT Indofood CBP Sukses Makmur, Tbk Periode 2007-2014 adalah sangat kuat. Selanjutnya Nilai koefisien determinasi ( $\mathrm{R}$ Square) adalah sebesar 0,785 atau $78,5 \%$ yang berarti bahwa secara bersama-sama Debt to Equity Ratio (DER) dan Working Capital Turnover (WCT) berpengaruh secara 78,5\% terhadap Return On Equity (ROE), sedangkan sisanya sebesar 21,5\% Return On Equity (ROE) dapat dipengaruhi variabel lain yang tidak ikut diteliti dalam penelitian ini, seperti Debt to Assets Ratio (DAR), Long Term Debt to Equity Ratio (LTDER), Total Assets Turnover (TAT), Fixed Assets Turnover (FAT), Inventory Turnover (IT), Return On Assets (ROA), Net Profit Margin (NPM).

\section{Saran}

a. Manajemen perusahaan hendaknya memperhatikan hutang dari pihak eksternal, karena semakin tinggi hutang maka akan makin tinggi risiko yang dihadapi. Namun, dengan tingkat risiko yang tinggi, hutang atau Debt to Equity (DER) yang tinggi juga dapat memberikan tingkat pengembalian yang tinggi pula. sebaiknya pihak manajemen perusahaan lebih mengutamakan aset yang ada agar tidak terjadi aset yang menganggur dan tidak dapat digunakan. Tingkat Working Capital Turnover (WCT) yang baik adalah jumlahnya yang selalu meningkat tiap tahunnya. Itu menandakan bahwa perusahaan dapat mengembalikan investasi yang dipercayakan kepada pihak perusahaan. Dengan demikian akan memberikan keuntungan dengan tingkat penjualan yang semakin meningkat.

b. Para investor seharusnya lebih ketat dalam mempertimbangakan keputusan untuk melakukan pendanaan yang terkait dengan hutang, perusahaan perlu mempertimbangakan keefektifan dan efesiensi dari hutang tersebut dalam menghasilkan profit bagi perusahaan dan para investor, karena seperti yang telah dibahas sebelumnya bahwa akan selalu ada trade-off antara tingkat pengembalian (return) dan risiko (risk), dimana penambahan hutang selain memabantu pendanaan bagi perusahaan akan tetapi juga disisi lain akan meningkatkan tingkat resiko dari perusahaan tersebut. Sebaiknya investor menganalisis tingkat hutang dan efisiensi perusahaan dalam mengelola aset. Sehingga investor dapat menanamkan modal kerja yang memberikan tingkat pengembalian seperti yang diharapkan.

c. Sehubungan dengan keterbatasan peneliti, mengharapkan pada peneliti lain untuk menamah variabel independen dapat di tambah untuk menjadikan hasil penelitian yang baik. Begitu juga sampel atau tahun penelitian dapat ditambah untuk menjadikan penelitian yang lebih menarik lagi.

\section{E. DAFTAR PUSTAKA}

Atmaja, Lukas Setia. 2003. Manajemen Keuangan, Edisi 2. Yogyakarta : Penerbit ANDI.

Brigham, Eugene F, dan Joel F. Houston. 2012. Dasar-Dasar Manajemen Keuangan: Essentials of Financial Management. Edisi Kesepuluh, Buku 2. Jakarta : Salemba Empat.

Horne, James C. Van dan John M. Wachowicz. 2013.Prinsip-prinsip Manajemen Keuangan. Edisi Ketigabelas, Jilid 1. Jakarta : Salemba Empat.

Kasmir. 2010. Pengantar Manajemen Keuangan. Edisi Pertama, cetakan ke-1. Jakarta : Kencana.

Margareth, Farah. 2011. Manajemen Keuangan untuk Manajer Perusahaan. Jakarta : Erlangga.

Riyanto, Bambang. 2009. Dasar-dasar Pembelanjaan Perusahaan. Edisi Keempat, Cetakan VI. Yogyakarta : BPFE UGM.

Rudianto. 2012. Pengantar Akuntansi. Adaptasi IFRS. Jakarta : Erlangga.

Stice, James D., Earl K. Stice dan K. Fred Skousen. 2009. Akuntansi Keuangan: Intermediate Accounting. Edisi Keenambelas, Buku 1. Jakarta : Salemba Empat.

Subramanyam. K. R, dan John J. Wild. 2010. Analisis Laporan Keuangan. Edisi Kesepuluh, Buku 2. Jakarta : Salemba Empat. 